\title{
Proposta de macroestrutura de um dicionário de provérbios brasileiros orientado a estudantes espanhóis de tradução
}

DOl: http://dx.doi.org/10.21165/el.v49i2.2465

\author{
Heloisa da Cunha Fonseca' \\ José Antonio Sabio Pinilla²
}

\section{Resumo}

Neste artigo, amparado pela teoria metalexicográfica e pela Fraseologia de vertente ampla, segundo a qual a parêmia é um arquilexema de outros tipos proverbiais, discutese como determinar a macroestrutura de um dicionário bilíngue de provérbios brasileiros orientado a estudantes espanhóis de tradução. Entende-se por macroestrutura o conjunto das entradas e a forma como o corpo do dicionário é organizado. Em razão disso, pondera-se sobre a extensão da nomenclatura, a seleção das unidades componentes, o tipo de organização das entradas, além do entrelaçamento entre macroestrutura, microestrutura e textos externos. As noções de usuário ideal e objetivo da obra apontam para uma nomenclatura seletiva, de unidades representativas da cultura brasileira, e para uma microestrutura profunda, centrada nas propostas de tradução e na problemática que envolve as equivalências. Essas questões são ilustradas com dois verbetes a fim de salientar que as parêmias têm um comportamento distinto da unidade lexical simples e, com frequência, modificam-se no discurso em virtude do contexto.

Palavras-chave: fraseologia; paremiologia; provérbios brasileiros; dicionário bilíngue; dicionário para aprendizes espanhóis de tradução.

1 União das Faculdades dos Grandes Lagos (UNILAGO), São José do Rio Preto, São Paulo, Brasil; heloisaibilce@gmail.com; https://orcid.org/0000-0001-9532-5147

2 Universidad de Granada (UGR), Granada, Espanha; jasabio@ugr.es; https://orcid.org/0000-0002-6185-8129 


\section{Propuesta de macroestructura de un diccionario de refranes brasileños dirigido a estudiantes españoles de traducción}

\section{Resumen}

Partiendo de la teoría metalexicográfica y de una concepción amplia de la Fraseología, que considera la paremia un archilexema de otras formas proverbiales, en este artículo se plantea cómo determinar la macroestructura de un diccionario bilingüe de refranes brasileños dirigido a estudiantes españoles de traducción. Pormacroestructura se entiende tanto el conjunto de entradas como la forma en la que el diccionario está organizado. Así, se tratan cuestiones como la extensión de la nomenclatura, la selección de las unidades y la organización de las entradas, además de la interrelación entre macroestructura, microestructura y textos externos. Con base en las nociones de usuario ideal y objetivo de la obra, se presenta una nomenclatura selectiva de refranes característicos de la cultura brasileña y una microestructura profunda, centrada en las propuestas de traducción y en los problemas de la equivalencia. Esos aspectos se ilustran con dos entradas que muestran cómo las paremias se comportan de modo diferente a las unidades léxicas simples y adquieren nuevos sentidos en función del contexto.

Palabras clave: fraseología; paremiología; refranes brasileños; diccionario bilingüe; diccionario para estudiantes españoles de traducción.

\section{Introdução}

Desde a década de 80, existe um consenso entre os pesquisadores de que os dicionários não podem dar conta de todo tipo de informação, mas devem estar concebidos com relação a dois fatores: objetivos da obra e público-alvo (BUGUEÑO MIRANDA, 2007). Nessa perspectiva, o possível consulente passa a ter posição central na determinação da estrutura do dicionário a ser desenvolvido. Assim, há de se fazer um esforço para pôr, lado a lado, o perfil do consulente e o tipo de obra que se deseja, pois desse paralelo emergem considerações relevantes para a consolidação do dicionário e as informações que delimitam a macroestrutura, mas também para a microestrutura e os textos externos, uma vez que tudo está relacionado.

Sob essas circunstâncias, pretende-se elaborar um dicionário de provérbios na direção português-espanhol, com vistas à consulta de alunos espanhóis de tradução. O perfil delineado é o de um estudante interessado em encontrar diferentes classes de equivalentes e informações culturais e tradutórias, a fim de auxiliar sua escolha e aumentar sua competência linguística em português. Neste artigo, procura-se discutir como determinar a macroestrutura de um dicionário de provérbios brasileiros dirigido a tal público. O projeto, que já foi apresentado à revista Guavira Letras (SABIO PINILLA, 2018), justifica-se pela carência de estudos e de teorias aplicáveis à elaboração de dicionários 
de provérbios, ainda mais quando o dicionário é bilíngue e destinado a aprendizes de tradução. Esse direcionamento implica uma obra com características únicas e, portanto, inédita, na medida em que foca nos comentários das propostas tradutórias oferecidas nos verbetes.

Para a execução do dicionário, partiu-se de pesquisas científicas anteriores que indicam que o tradutor é um usuário assíduo dos dicionários bilíngues, "sobretudo quando procura precisar, na língua para a qual traduz, o termo que melhor designe a noção apresentada no texto a ser traduzido", como assinalado por Xatara (1998, p. 179). Esta preferência pelos dicionários bilíngues foi verificada em um estudo empírico realizado por Corpas Pastor, Leiva Rojo e Varela Salinas (2001) mediante questionários aplicados aos estudantes de Tradução e Interpretação da Universidade de Málaga, Espanha, investigação que servirá de guia para muitas das escolhas e decisões no decorrer do processo.

Na sequência, refletimos sobre a forma como o corpo desse dicionário tem sido organizado, para isso, discutiremos a disposição das entradas, a seleção dos lemas e o tamanho da nomenclatura. Pretende-se também ressaltar a relação entre as partes das obras lexicográficas e a macroestrutura, mostrando que as escolhas feitas em um nível refletem nas decisões tomadas em outro, isto é, textos externos, macroestrutura e microestrutura estão relacionados e são direcionados pelos objetivos da obra e o ideal de consulente. Para esse percurso, adotou-se uma concepção ampla da Fraseologia, em que a parêmia é vista como uma unidade fraseológica abrangente de outros elementos proverbiais, tudo isso tendo em conta a necessidade de dicionários adequados ao nível de conhecimento de língua estrangeira do usuário e ao objetivo de uso das obras de referência.

\section{Pressupostos teóricos}

No âmbito dos estudos fraseológicos, há duas possibilidades de entender a Fraseologia: uma restrita e outra mais ampla. Por um lado, há aqueles que aderem a uma fraseologia com sentido restrito e admitem a existência de uma disciplina complementar, mas apartada, "que seria responsável pelo estudo das unidades que tendem a se comportar mais como textos e menos como palavras, a Paremiologia [...] disciplina que integra aspectos etnográficos e antropológicos observáveis nas parêmias" (FONSECA, 2017, p. 22). Por outro lado, estão aqueles que admitem a Fraseologia em sentido amplo e consideram que todas as unidades fraseológicas, incluídas as parêmias, são objeto de estudo da Fraseologia, pois todas elas podem ser consideradas fraseologismos. Adotamos esta segunda opção reconhecendo, no entanto, as características específicas das parêmias. 
Nesse contexto, Sevilla Muñoz e Crida Álvarez (2017, p. 118, tradução nossa³) definem parêmia como "uma unidade fraseológica (UF) constituída por um enunciado breve e sentencioso, que corresponde a uma oração simples ou composta, fixada na fala e que faz parte do acervo sociocultural de uma comunidade falante". Apesar de a definição ser bastante interessante, pois ressalta o caráter discursivo e sociocultural das parêmias, não abarca uma série de características que podem ajudar a delimitar esse objeto multifacetado e abrangente, como se observa:

O termo "parêmia" vai sendo difundido entre os pesquisadores de língua espanhola desde os anos 80 do século XX, e é usado como um "arquilexema" (Sevilla, 1988, p. 231) ou "hiperônimo" (Corpas, 1996, p. 135) das unidades linguísticas que compõem o universo paremiológico, que engloba os termos: provérbio, ditado, máxima, sentença, frase proverbial, adágio, provérbio dialogado, apotegma, além de muitas outras denominações. (SEVILLA MUÑOZ; CRIDA ÁLVAREZ, 2017, p. 118, tradução nossa4).

Entre os termos que compõem o que se conhece por parêmia estão os provérbios, que possuem as seguintes características: são unidades breves e concisas que normalmente refletem uma verdade aceita por todos; são autônomas e podem inserir-se diretamente no discurso ou com uma leve adequação; apresentam um elevado grau de fixação e uma estrutura muitas vezes bimembre, com elementos rítmicos e retóricos que facilitam sua memorização. Neste trabalho, o termo provérbio terá uso análogo à parêmia.

Assim, a parêmia pode ser considerada um arquilexema que abarca diversos tipos de unidades ou enunciados sentenciosos que têm em comum algumas características básicas, como as apontadas por Corpas Pastor (1996): a) fixidez, que se observa na ordem dos constituintes, nas categorias gramaticais, no inventário dos componentes e na visão de mundo que fazem transparecer; b) conteúdo sentencioso e c) possibilidade de idiomaticidade, de variação e de pragmaticidade.

Por serem unidades fixadas de discurso, as parêmias tendem a seguir uma determinada disposição, ou seja, seus componentes aparecem na mesma ordem e em companhia das mesmas unidades lexicais, ou de um grupo muito restrito delas, como se vê em

3 No original: "una unidad fraseológica (UF) constituida por un enunciado breve y sentencioso, el cual corresponde a una oración simple o compuesta, que se ha fijado en el habla y que forma parte del acervo socio-cultural de una comunidad hablante.".

4 No original: "El término "paremia" se va imponiendo entre los investigadores de lengua española desde la década de los 80 del siglo XX, y es usado como "archilexema" (Sevilla, 1988: 231) o "hiperónimo" (Corpas, 1996: 135) de las unidades lingüísticas que componen el universo paremiológico, el cual engloba los términos: proverbio, refrán, máxima, sentencia, frase proverbial, adagio, dialogismo, apotegma, así como un extensísimo etcétera.". 
"quem com ferro fere, com ferro será ferido", que consiste em uma advertência sobre a circularidade das más ações, assim, quem faz o mal também recebe o mal. A alteração dessa estrutura pode causar estranhamento: ${ }^{*}$ com ferro será ferido, quem com ferro fere / *quem com ferros fere, com ferros será ferido / *quem com ferro machucar, com ferro será machucado ou, até mesmo, levar ao não reconhecimento do significado cultural compartilhado. No entanto, há uma possibilidade de variação com relação ao contexto de ocorrência, o que deve ser tomado em termos de continuum, que vai das pequenas às grandes mudanças de significado das parêmias.

Dessa forma, segundo Fonseca (2017), a variação é uma mudança na forma da unidade fraseológica que não altera o significado, como no exemplo "quem anda com porcos, farelo come" e "quem anda com porco, farelo come"; a derivação é uma mudança de significado que não altera a forma, como se observa em "caiu na rede é peixe", em que "rede" faz referência à internet; e a desautomatização altera forma e conteúdo, mas sempre mantendo relação com o fraseologismo de base, o que se vê num uso recente de "quem com grampo fere, com grampo será ferido", com relação aos grampos de telefone utilizados por juiz e procurador brasileiros, que também foram, posteriormente, grampeados por uma terceira pessoa.

Nesse contexto de variações e alterações, e com base no apontamento de Corpas Pastor (1996) de que é possível haver mudanças tanto formais como pragmáticas, é que se concebeu este dicionário de provérbios para estudantes espanhóis de tradução, pois são os casos em que os dicionários gerais deixam a desejar. Primeiro, em razão dos dicionários gerais não registrarem unidades complexas e textuais como entradas independentes, sendo mais comum o registro como subitem de uma unidade componente ou sua omissão, por serem considerados do uso comum; segundo, por proporem um equivalente único, pouco adaptável às mudanças semânticas ocasionadas pelo entorno textual em que ocorrem.

Por sua vez, os dicionários bilíngues não prestam suficiente atenção a essas unidades fraseológicas e propõem equivalentes que parecem recobrir todas as situações de uso. No tocante à microestrutura, esta carência é ainda maior, uma vez que são escassos, por não dizer inexistentes, os trabalhos dedicados a analisar e definir uma microestrutura adequada para elaborar um dicionário de provérbios $^{6}$, especialmente se centrado na tradução. Nesse sentido, Zavaglia (2001, p. 54) pondera:

5 Disponível em: https://tinyurl.com/y5kk4ycr. Acesso em: 12 jul. 2019.

60 interesse dos especialistas tem se focado nas locuções e, mais exatamente, nas locuções verbais pelo fato de estas unidades fraseológicas terem grande prestígio entre os lexicógrafos e, por isso, serem tratadas em muitos trabalhos fraseográficos, como acontece no livro de Olímpio de Oliveira Silva (2007). Outros trabalhos dedicados a estas unidades são a tese de mestrado de Mattos (2010) para as locuções verbais português-espanhol e a proposta de dicionário de locuções de espanhol de Penadés Martínez (2015). Pode-se citar também a tese de Riva (2009) para as expressões idiomáticas. 
[...] na elaboração de obras lexicográficas bilíngües e/ou semibilíngües, verificamse problemas de equivalência de lexias, levando o lexicógrafo-tradutor a refletir sobre tais questões e a exercitar sua capacidade de encontrar e propor expedientes lingüísticos que satisfaçam os valores semânticos desses itens lexicais da língua de partida na língua de chegada.

Este trabalho, portanto, vai ao encontro do que foi exposto por Zavaglia (2001) e faz uma proposta alternativa, diferente das obras vistas e consultadas até hoje, que leva em consideração o comportamento excepcional das parêmias e as necessidades de um perfil de usuários muito específicos: estudantes espanhóis de tradução.

\section{Macroestrutura}

O conceito de macroestrutura, que aqui se admite, relaciona-se a uma noção conciliadora entre a nomenclatura da obra lexicográfica e sua ordenação, tendo em vista a evidente implicação de que todo conjunto de unidades deve apresentar algum tipo de disposição. Esta concepção está de acordo com a de Bugueño Miranda (2007, p. 262) para quem a macroestrutura "diz respeito tanto ao universo léxico que o dicionário deve conter, como à ordenação e tratamento da nominata". Os tópicos que se fazem caros à determinação da macroestrutura do dicionário proposto podem ser percebidos na definição acima e fazem referência às unidades a serem lematizadas e, portanto, aos critérios de seleção e delimitação de tamanho e de conteúdo e, obviamente, de ordenação desses lemas.

Bugueño Miranda (2007) ainda especifica que a relação entre dicionário e usuário pode ser estabelecida de acordo com dois princípios: um linguístico e outro fenomenológico. 0 princípio linguístico determina em que perspectiva forma e conteúdo serão abordados, fato que influi diretamente na ordenação das entradas. Se o foco é a forma, o direcionamento ocorre do significante para o significado, o que caracteriza uma disposição semasiológica; se o foco é o significado, o direcionamento é inverso, vai do significado para o significante, o que caracteriza uma ordenação onomasiológica.

As duas formas de organização são bastante discutidas visto que "sobre a semasiologia recaem críticas de que não favorece o entrelaçamento de unidades correlatas e sobre a onomasiologia recai o julgamento de que a separação em campos semânticos ou conceitos é abstrata e subjetiva" (FONSECA, 2017, p. 67). Para contornar esse impasse, preferiu-se tomar por base uma pesquisa anterior, desenvolvida por Corpas Pastor, Leiva Rojo e Varela Salinas (2001), em que os autores levantaram, através de questionários, as obras mais procuradas por estudantes de tradução da Universidade de Málaga, Espanha, e chegaram à conclusão de que: 
[...] a informação mais procurada é a que a situação de trabalho ou de estudo exige diretamente, isto é, aquela que resolve os problemas de tradução ou compreensão de um texto. Esta étambém a principal razão que explica a esmagadora preferência dos estudantes por dicionários bilíngues gerais: eles constituem uma fonte de documentação prática e econômica. [...] Os usos mais frequentes do dicionário bilíngue geral são, portanto, a produção e compreensão de leitura na segunda língua, de um lado, e, de outro, a tradução nos dois sentidos. (CORPAS PASTOR; LEIVA ROJO; VARELA SALINAS, 2001, p. 251, tradução nossa7).

Levando-se em consideração os resultados desta pesquisa ${ }^{8}$, entre eles, o de que os alunos espanhóis de tradução preferem dicionários bilíngues e semasiológicos, pretendese proceder a uma organização semasiológica, do significante ao significado. Além disso, acredita-se que, para as unidades poliléxicas, a organização em ordem alfabética deixa a busca mais intuitiva e rápida.

O princípio fenomenológico permite formulações baseadas na oposição entre dois critérios: dicionários de língua abrangentes e dicionários de língua seletivos. A visão abrangente faz referência aos dicionários de língua geral e a seletiva aos inventários não abertos, como é o caso de dicionários de provérbios. Para os dicionários de inventário seletivo, "é necessário criar parâmetros de seleção macroestrutural" (BUGUEÑO MIRANDA, 2007, p. 265); esses princípios de seleção devem ser estabelecidos pelo próprio lexicógrafo a partir dos quesitos básicos citados: estudante espanhol de tradução que tem o português como língua de estudo e precise consultar uma obra para traduzir provérbios marcadamente brasileiros.

Sob essa égide, delineou-se uma série de questões para estabelecer a natureza do tipo de unidade que realmente deve ocupar um lugar na macroestrutura do dicionário, como se observa a seguir:

Quais provérbios poderão compor o dicionário?

7 No original: "la información más buscada es la que la situación laboral o de estudio pide directamente: esto es, la que soluciona los problemas de traducción o comprensión de un texto. Ésta es también la razón primordial que explica la preferencia aplastante de los alumnos por los diccionarios bilingües generales: constituyen una fuente de documentación cómoda y económica. [...] Los usos más frecuentes del diccionario bilingüe general son, pues, la producción y comprensión lectora en la segunda lengua, por un lado, y, por el otro, la traducción en ambas direcciones.".

8 Isto é fundamental, apesar de parecer óbvio, como assinala Penadés Martínez (2015) a propósito da lematização de um dicionário de locuções, em que um dos problemas é o de que não há análises sobre o uso que os consulentes fazem dos dicionários. 
(03) Como determinar o que é especificamente brasileiro? Apenas os usados no Brasil ou aqueles de língua portuguesa que têm uma maior frequência de uso no Brasil?

\section{Qual é o tamanho da nomenclatura?}

A primeira questão levantada é parcialmente respondida pelo próprio objetivo deste projeto, que visa dar opções aos estudantes espanhóis com relação à tradução de provérbios brasileiros. Nesse sentido, o objeto que se pretende coletar, analisar e registrar são as parêmias que circulam e compõem a competência linguística e cultural do brasileiro e, em razão disso, podem ter uso mais frequente na língua escrita.

As construções "todo mundo só vê as pingas que tomo, mas não vê os tombos que levo" e "cu de bêbado não tem dono", apesar de características do Brasil, não serão registradas por comporem formulações mais associadas à oralidade ou à linguagem escrita que a reproduz. Isso foi observado no decorrer das buscas por contextos em páginas web, em que unidades como as citadas tendem a aparecer em comentários, réplicas e ponderações pessoais, situações em que predomina o uso informal da língua, mais próximo à fala. Já uma série do tipo "muito ajuda quem não atrapalha" é mais reproduzida em textos escritos, porém, corresponde a uma formulação menos opaca que não ressalta o caráter cultural brasileiro, o mesmo pode ser percebido em "falem mal, mas falem de mim".

Assim, uma das inquietações na elaboração de uma obra com este perfil é determinar o que é estritamente brasileiro no âmbito da língua portuguesa e o que, sendo brasileiro, carregue uma carga cultural marcada. Dessa maneira, compreende-se que a cultura determinaria as criações lexicais que, por sua vez, determinam as criações fraseológicas: "um dos fatores que indica o entrelaçamento do cultural no lexical é a possibilidade de produzir ou de compreender as expressões figuradas constituídas por expansão a partir de palavras em que o referente já é por si próprio um símbolo na cultura da comunidade" (PAMIES BERTRÁN, 2008, p. 143, tradução nossa).

Com base no exposto, visa-se identificar aquelas unidades do universo de provérbios brasileiros de marcado caráter cultural, dado que a cultura perpassa todos os níveis da organização social, o que se mantém também no plano linguístico. Portanto, para a seleção da nomenclatura, pretende-se conciliar um conjunto representativo de provérbios da língua padrão do Brasil com outro grupo de provérbios talvez menos frequentes, a fim de salientar aspectos históricos e culturais. É o que se nota em "rapadura é doce, mas

9 No original: "L'un des facteurs qui manifestent l'emboîtement du culturel dans le lexical est la possibilité de produire ou de comprendre les expressions figurées construites par expansion à partir de mots dont le référent est déjà lui-même un symbole dans la culture de la communauté.". 
não é mole, não" e "pimenta nos olhos dos outros é refresco", provérbios que se referem a elementos da cultura alimentícia brasileira, rapadura e pimenta, e suas características, doce, dura, picante etc. Além disso, esses provérbios equilibram-se entre o registro oral e o registro escrito, são estruturas mais opacas do ponto de vista idiomático e conservam a característica primordial das parêmias que é o caráter pedagógico, ou seja, dão advertência e aconselhamento moral nos termos da cultura da qual emergem e fazem parte.

Mesmo que se esclareça o quesito cultura, ainda há de se determinar o que é do âmbito da língua portuguesa do Brasil. Para isso, admite-se a necessidade de entrelaçamento entre três recursos de pesquisa: a web, os dicionários e os corpora. Utiliza-se a web como fonte para o levantamento e seleção de parêmias, definições e contextos, uma busca que se faz pela ferramenta da pesquisa avançada, que restringe, o máximo possível, o universo digital de textos.

Com relação aos fraseologismos, a web apresenta-se como um meio de investigação muito importante, pois condensa variações e ocorrências legítimas que observamos no uso cotidiano da linguagem, dado o grau de fixidez e a espontaneidade do uso. Além do conteúdo e dos diferentes tipos textuais, podemos utilizar também a web com buscadores automáticos, estabelecendo parâmetros de pesquisa para que os dados sejam os mais homogêneos possíveis, isto é, estabelecer parâmetros e aplicar as mesmas regras de busca a todos os textos [...].(FONSECA, 2016, p. 460, tradução nossa ${ }^{10}$ ).

As obras de referência são outro rico recurso de pesquisa, como dicionários especiais e dicionários gerais do português europeu e brasileiro, alguns dicionários consultados são: Tesouro da fraseologia brasileira (NASCENTES, 1945), Adagiário brasileiro (MOTA, 1982), 0 Grande Livro dos Provérbios (MACHADO, 1996), Dicionário de provérbios: francês, português, inglês (LACERDA; LACERDA; ABREU, 1999), O Livro dos Provérbios (PARENTE, 2005), PIP - Dicionário de provérbios, idiomatismos e palavrões francês-português / portuguêsfrancês (XATARA; OLIVEIRA, 2008), Dicionário brasileiro de expressões idiomáticas e ditos populares (URBANO, 2018), além dos dicionários gerais Dicionário da Língua Portuguesa Contemporânea (CASTELEIRO, 2001), Dicionário Eletrônico Houaiss de Língua Portuguesa (HOUAISS; VILLAR, 2009), Novo Dicionário Eletrônico Aurélio (FERREIRA, 2010) ou Dicionário Online Caldas Aulete (AULETE; VALENTE, 2019).

10 No original: “En relación a los fraseologismos, la web se presenta como un medio muy importante de investigación, pues condensa variaciones y ocurrencias legítimas que observamos en el uso cotidiano del lenguaje, dado el grado de fijación y la espontaneidad del uso. Además del contenido y de los diferentes tipos textuales, podemos utilizar también la web con buscadores automáticos, estableciendo parámetros de búsqueda para que los datos sean lo más homogéneos posible, es decir, establecer parámetros y aplicar las mismas reglas de búsqueda a todos los textos [...].". 
Posteriormente, em razão dos debates em eventos científicos, constatou-se também a necessidade de uso da Linguística de Corpus, amplamente explorada por pesquisadores do léxico. Uma das ferramentas à disposição é o Corpus do Português: NOW'11, que permite confrontar as frequências de uso no Brasil com as de outros países falantes de língua portuguesa. Cada uma dessas fontes aporta informações distintas que, juntas, dão pistas para o objeto que se pretende recolher e servirão para selecionar definitivamente a nomenclatura.

Tendo em vista o objeto e o consulente deste dicionário, a questão da extensão da macroestrutura fica dependente de uma condição básica: o suporte da publicação. De acordo com Welker (2004, p. 83), "o fator mais importante no que concerne ao tamanho da nomenclatura é, obviamente, a determinação do lexicógrafo ou da editora a respeito do tipo de dicionário que quer produzir". Nesse contexto, contempla-se em princípio uma obra impressa, devido a algumas dificuldades administrativas de liberação de hospedagem e domínio.

Consequentemente, este fator vem associado à estrutura interna do verbete. Quanto mais informação é inserida após o lema, mais extensa é a obra como um todo, uma vez que "a microestrutura de base [...] é composta das informações ordenadas que seguem a entrada e têm uma estrutura constante, correspondendo a um programa e a um código de informações aplicáveis a qualquer entrada" (BARBOSA, 1999, p. 41). Dessa maneira, pensou-se em uma nomenclatura seletiva em que uma macroestrutura curta possa ser balanceada por uma microestrutura profunda.

No caso de adoção de um modelo eletrônico, a extensão das entradas e a organização interna delas deverão ser repensadas, tendo em conta a discussão anterior; porém, até a determinação desse aspecto, o presente artigo detalha o trabalho que tem sido feito para a elaboração da obra descrita. Nesse sentido, as informações que se concebem importantes para a composição da microestrutura deste dicionário são: entrada, variantes, definição, contextos, traduções dos contextos, comentários tradutológicos e observações. É por não perder de vista o estudante espanhol de tradução que as traduções dos contextos e seus comentários foram privilegiados em detrimento de outras informações, como classificação da parêmia na gama das unidades fraseológicas, por exemplo.

\section{Implicações gerais}

Os dois quesitos que norteiam a elaboração de um dicionário, tipo de obra e público-alvo, influenciam não só as decisões macroestruturais, mas interferem também na articulação de todos os componentes do dicionário, o que Hartmann e James (1998, p. 93 apud WELKER, 2004, p. 79) chamaram de "megaestrutura". Sem entrar profundamente no mérito

11 Disponível em: https://www.corpusdoportugues.org/now/. Acesso em: 07 maio 2020. 
das delimitações conceituais, há uma interrelação entre textos externos, macroestrutura e microestrutura, por mais que sejam, muitas vezes, explorados separadamente nos compêndios metalexicográficos. Assim, a decisão de abordar as parêmias brasileiras em uma obra pensada para estudantes espanhóis de tradução, como vimos, direciona uma série de providências macroestruturais, no entanto, elas influenciam e são influenciadas por decisões microestruturais, como a complexidade do verbete, por exemplo, que por sua vez vai indicar que tipo de explicação aprofundar nos textos externos.

Nesse sentido, foram separados dois provérbios para ilustrar como se delineou um dicionário para estudantes espanhóis de tradução, acreditando-se que, desse modo, seja mais fácil mostrar as implicações que foram mencionadas acima.

Imagem 1. Primeiro exemplo de verbete

\begin{tabular}{|c|c|}
\hline \multicolumn{2}{|c|}{ Quien es responsable de algo o de alguien, debe asumir las consecuencias. } \\
\hline 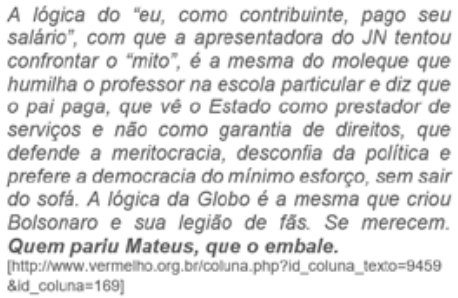 & $\begin{array}{l}\text { La lógica del "como yo soy contribuyente, le pago } \\
\text { su salario", con la que la presentadora del JN } \\
\text { (Jornal Nacional) hizo frente al "mito", es la misma } \\
\text { del niñato que humilla al profesor en la escuela } \\
\text { privada diciendo que su padre le paga, que ve al } \\
\text { Estado como prestador de servicios y no como } \\
\text { garantía de derechos, que defiende la } \\
\text { meritocracia, desconfia de la politica y prefiere la } \\
\text { democracia del mínimo esfuerzo, sin moverse del } \\
\text { sofá. La lógica de la cadena Globo es la misma } \\
\text { que creó a Bolsonaro y a su legión de fans. Se lo } \\
\text { merecen. Que cada palo aguante su vela. }\end{array}$ \\
\hline
\end{tabular}

- Existe en español un equivalente natural con igual valor semántico y la misma frecuencia de uso. En la traducción, se han explicitado las referencias al informativo "JN" y a la cadena "Globo".

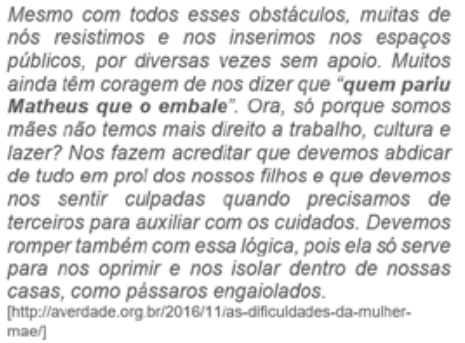

nós resistimos e nos inserimos nos espaços públicos, por diversas vezes sem apoio. Muitos ainda têm coragem de nos dizer que "quem pariu Matheus que o embale". Ora, so porque somos máes náo temos mais direito a trabalho, cultura e de tudo em prol dos nossos filhos e que devemos nos sentir culpadas quando precisamos de romper também com essa lógica, pois ela só serve para nos oprimir e nos isolar dentro de nossas casas, como pássaros engaiolados. mael)

A pesar de todos estos obstáculos, muchas de nosotras resistimos y participamos en los espacios públicos, a veces sin apoyo. Muchos incluso tienen el descaro de decirnos que "cada palo aguante su vela". ¿Acaso por ser madres no tenemos ya derecho al trabajo, a la cultura $y$ al ocio? Nos hacen creer que debemos renunciar a todo por nuestros hijos y que debemos sentirnos culpables cuando necesitamos la ayuda de cerceros para cuidarios. Debemos romper también con esta logica, pues solo sirve para oprimirnos y fuéramos pájaros enjaulados.

\begin{abstract}
- El equivalente natural en español funciona también en esta propuesta de traducción, por inferencia aunque se pierda la relación con la idea de "maternidad" transmitida por el refrán en portugués a través del verbo "parir".

Cunha é um emérito blefador, mas não tem cacife para reunir 342 votos contra o governo se os tucanos não votarem com ele. Se tudo o que é tucanos não votarem com ele. Se tudo o que é
sólido dosmancha no ar, imagine-se algo insólito como esse impeachment. aborta-lo. A palavra de ordem em Brasilia é: quem
pariu o impeachment que o embale.

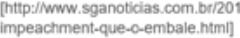

Cunha es un reputado embaucador, pero no tiene capacidad para reunir 342 votos contra el gobierno si los diputados del PSDB (Partido de la Social Democracia Brasileña) no votan con él. Si todo to sólido se deshace en el aire, imaginese algo tan insólito como este impeachment. EI problema es cómo abortario. El lema en Brasilia es: quien creó el impeachment que lo solucione.

- El refrán brasileño puede adecuarse al discurso mediante la inclusión en el espacio vacío, marcado por el paréntesis, de alguna referencia. Este recurso es muy utilizado en el lenguaje político, como se ve en este contexto. El traductor ha de proponer una solución que se adapte a cada caso: en nuestra propuesta hemos reproducido el refrán mediante una paráfrasis. Además, hemos mantenido "impeachment", en vez de traducirlo por "proceso de destitución", y hemos explicitado la alusión a
\end{abstract} "tucanos".

Fonte: Elaboração própria 
Como é sabido, há parêmias que apresentam um equivalente mais ou menos fixo que é indicado pelo dicionário com base na definição, ou explicação semântica, e no comportamento desta unidade na maioria dos discursos. Essa conjuntura permite uma tradução mais natural, pois o equivalente opera na maioria dos casos, como ocorre com "quem pariu Mateus que o embale" que poderia ser traduzido ao espanhol por "que cada palo aguante su vela". Assim, nos dois primeiros contextos, percebe-se que a tradução explorou a frase proverbial equivalente, com igual valor semântico e frequência de uso, mas no último caso, devido à atualização discursiva do provérbio brasileiro, a proposta de tradução emprega uma paráfrase baseada na proximidade da forma original.

Nessa sequência, como assinalou Xatara (1998), é preciso distinguir entre aquela tradução que aparece no dicionário, que ficaria no nível da língua, e aquela tradução que procura uma equivalência funcional ou situacional e que se aproxima do discurso. A primeira pode ser denominada de correspondência e a segunda de equivalência. Segundo Zuluaga (2001, p. 68, tradução nossa ${ }^{12}$ ), "as equivalências - que são unidades do texto - nem sempre coincidem com as correspondências, que são unidades do sistema. Por isso, no processo de tradução é apenas parcial a ajuda dos dicionários bilíngues e da linguística contrastiva".

No dicionário que apresentamos, formado por provérbios brasileiros marcados culturalmente, o nosso intuito não é oferecer uma relação de correspondências primárias, abstratas e descontextualizadas (CORPAS PASTOR, 2001), como acontece na maioria dos dicionários, mas propor diversas traduções com um valor equivalente da parêmia brasileira, sempre que possível, a partir de contextos autênticos de uso. Desse modo, pretende-se salientar com esta obra que as parêmias têm um comportamento distinto da unidade lexical simples e, na maioria dos casos, não mantêm uma relação biunívoca com o que poderia ser considerado equivalente, a correspondência dos dicionários tradicionais, pois há uma instabilidade do sentido decorrente da atualização no ambiente discursivo novo, o que abre novas possibilidades de efeitos de sentido. Antecipando esse tipo de ocorrência, deu-se maior relevo às traduções e comentários tradutórios. Nessa lógica, afırmamos que a macroestrutura seria curta ao passo que a microestrutura seria profunda.

Para o segundo exemplo, "em rio que tem piranha, jacaré nada de costas", não se encontrou um correspondente formal ou funcional, mas, no momento da tradução de cada contexto, optou-se pelo uso de uma unidade também idiomática com o objetivo de manter a expressividade que é trazida pelo provérbio e assegurar a equivalência comunicativa.

12 No original: "Las equivalencias -que son unidades texto- no siempre coinciden con las correspondencias, que son unidades del sistema. Por esto, en el proceso de traducción es apenas parcial la ayuda de los diccionarios bilingües y la de la lingüística contrastiva.". 
Imagem 2. Segundo exemplo de verbete

\section{em rio que tem piranha, jacaré nada de costas}

|em rio de piranhas, jacaré nada de costas / em rio de piranha, jacaré nada de costas|

En determinadas situaciones hay que ser desconfiado y prevenirse contra los peligros.

Diz-se que em rio que tem piranha jacaré nada de costas. O trânsito ficou tão complicado e os perigos aumentam tanto a cada dia que este motociclista armou uma gaiola de proteção na sua scooter - perdão, motoneta. Laterais e até o teto da moto flagrada na foto contam com o equipamento que em carros de corrida é chamado de santantônio. Se a moda evoluir, em breve teremos vidros e portas nas laterais, teto e voilà! inventaram o automóvel!

[https://www jornaldocomercio.com/site/noticia. php?codn! $=60395$
Suele decirse que hay que saber nadar y guardar la ropa. El tráfico se ha complicado tanto y los peligros han aumentado tanto cada día que este motociclista montó una jaula de protección en su scooter, perdón, motocicleta. Los laterales y hasta el techo de la moto, recogida en la foto, cuentan con un equipamiento que en los coches de carreras se llaman barras de seguridad. Si la moda evoluciona, pronto tendremos ventanas $y$ puertas en los laterales, techo $y$, entonces, ihabremos inventado el automóvil!

- Este refrán no tiene un equivalente natural en español por lo que será necesario adaptarlo en función del contexto. En este caso, se ofrece un equivalente contextual mediante el refrán "saber nadar y guardar la ropa" para transmitir la idea (parcial) de prevención que recupera el elemento "nadar" del original.

Com toda essa história, não é de admirar que sejamos seres mais para desconfiados e defensivos do que seres propensos a confiar e a ter fé em nós mesmos, nos outros e no mundo. Na guerra, todos têm razão para desconfia de todos. A brincadeira de que "em rio que tem piranha, jacaré nada de costas" é uma boa metáfora para o clima da maioria de nossas relações. [https://tinyurl.com/y5wpkyrb]
Con toda esa historia, no ha de extrañarnos que seamos más seres desconfiados y defensivos que seres propensos a confiar y a tener fe en nosotros mismos, en los otros y en el mundo. En la guerra, todos tienen razón para desconfiar de todos. La frase "en la confianza está el peligro" es una buena metáfora para definir el clima de la mayoria de nuestras relaciones.

- De nuevo se ofrece un equivalente contextual tomando como base, en esta ocasión, la idea de la desconfianza en las relaciones humanas transmitida por el refrán "en la confianza está el peligro". La traducción propuesta procura adaptarse al contenido del original ya que la traducción literal, como en el ejemplo anterior, no tendría sentido en español.

Também conheci uma cidade onde condutor de moto só podia entrar em posto de gasolina empurrando a moto e sem capacete. Já é um extremo mas em rio de piranha jacaré nada de costas. Pensar que só com motos se fazem assaltos é um ledo engano mas a maior incidência de crimes tem sido com o uso deste tipo de veículo pela facilidade que tem de aproximação, fuga e ocultação do reconhecimento facial pelo capacete, quase uma toca ninja.

[http://jornalsemanario.com.br/acao-reacao-e-oracao/]
También conoci una ciudad donde los motoristas solo podian entrar en las gasolineras empujando la moto y sin casco. Parece un poco exagerado, pero más vale prevenir que curar. Pensar que solo se asaltan las gasolineras con moto denota cierta ingenuidad, aunque la mayor incidencia de este tipo de delitos se produce con este vehículo debido a lo fácil que resulta llegar y huir sin ser reconocido por llevar el casco puesto, a modo de capucha ninja.

Como en los contextos anteriores, el traductor debe proponer una unidad fraseológica que transmita una idea aproximada. En este caso, se ha optado por "más vale prevenir que curar", un refrán que asegura la equivalencia comunicativa entre ambos textos a pesar de que en portugués existe "mais vale prevenir do que remediar".

Fonte: Elaboração própria

Como se pode notar, cada unidade foi escolhida segundo a observação do contexto, resultando em "hay que saber nadar y guardar la ropa", "en la confianza está el peligro" e "más vale prevenir que curar". Por conseguinte:

Uma boa tradução deve levar em conta não apenas seu conteúdo, mas também seu uso segundo a situação de comunicação, o que compreende grau de relação entre emissor / receptor, diversidade entre o oral e o escrito e grau de ajuste do emissor ao receptor, além das considerações de ordem sociolinguística. (XATARA, 1998, p. 62). 
A tradução fraseológica evoca no usuário da outra língua uma imagem, que poderá ser mais ou menos expressiva, apesar de muitas vezes não ser representada da mesma forma e com os mesmos elementos linguísticos. No entanto, nem sempre um correspondente fraseológico é possível, cabendo ao tradutor a tarefa de avaliar na língua de chegada e no contexto de uso qual tipo de tradução é o mais indicado.

Assim, em um dicionário de provérbios característicos da língua portuguesa do Brasil, é frequente encontrar casos sem correspondência em espanhol; em vista disso, propomos traduções de diferentes contextos em que aparece o provérbio a fim de orientar as escolhas dos consulentes. Além das indicações tradutórias dadas nos dois exemplos anteriores, podemos deparar com outras que vão da transferência direta ou da tradução literal da parêmia brasileira à substituição por uma nova parêmia criada a partir das características estruturais dessas unidades fraseológicas de base, passando por outras técnicas como a substituição por outro fraseologismo, a paráfrase ou, até mesmo, a omissão (SABIO PINILLA; DÍAZ FERRERO, 2018).

Nessa lógica, a melhor solução será aquela que condiz com a situação comunicativa de cada contexto, conservando, se possível, a parêmia ou a unidade fraseológica. Seja como for, o aluno deverá ser informado do caráter relativo das equivalências, questão que poderia ser explicada globalmente na introdução da obra e especificada nos comentários tradutológicos e observações de cada verbete. Todavia, a estrutura do verbete deve ser sempre igual, embora, em certos casos, o nível de detalhamento possa variar em função de cada provérbio: número de variantes, acepções, equivalentes que não recobrem na totalidade o sentido do provérbio brasileiro ou até falta de equivalência. Todos esses aspectos poderiam demandar um desenvolvimento mais aprofundado da informação, o que implicaria verbetes mais extensos.

Uma obra de referência, portanto, deve ser pensada no todo. À medida que se aprofunda no objeto de análise, admite-se também uma série de características que são próprias a ela, mas que não devem ser tratadas isoladamente, pelo contrário, devem ser tratadas tendo em conta o consulente da obra. Como este é um dicionário para aprendizes, manteve-se a preocupação de comentar cada escolha tradutória para que os alunos possam se basear e tomar decisões de maneira mais fundamentada.

As explicações tradutórias, por sua vez, ocasionam a necessidade de explicações mais detalhadas no texto externo. Neste apartado dedicado à introdução da obra e às instruções de uso, o que se descreve é diretamente dependente da organização macro e microestrutural. É nesse espaço que se cogita justificar a elaboração de um dicionário de provérbios brasileiros para estudantes espanhóis de tradução e apresentar: os objetivos, os pressupostos teóricos e, sobretudo, o sistema de consulta da obra, com especial relevo para a abordagem tradutológica das unidades selecionadas. 
Concebe-se, assim, que tanto os contextos como as traduções e comentários possam desenvolver um papel pedagógico auxiliando o aluno a perceber matizes de sentido, a buscar equivalentes mais significativos na língua meta e, ainda, a entender que as estratégias e as técnicas de tradução a elas associadas são diversas e podem ser adotadas de acordo com as particularidades de cada caso.

\section{Considerações finais}

No decorrer destas páginas, apresentamos uma proposta de macroestrutura de um dicionário de provérbios brasileiros orientado a estudantes espanhóis de tradução. Justificamos o projeto pela carência de estudos e de teorias aplicáveis à elaboração de dicionários de provérbios, no nosso caso, um dicionário semasiológico bilíngue português-espanhol, cuja função principal é auxiliar na tradução. Para isso, adotamos uma concepção ampla da Fraseologia, em que a parêmia é tida como uma unidade fraseológica abrangente de outros elementos proverbiais, e levamos em consideração o perfil do usuário e o objetivo de uso da obra. Assim, este trabalho pode ser considerado original, com características únicas, já que além de focar a atenção numa unidade fraseológica pouco estudada do ponto de vista lexicográfico, centra-se nos problemas e estratégias de tradução das parêmias e nos comentários das propostas tradutórias oferecidas nos verbetes.

Ao longo do artigo discutiu-se a forma como o corpo deste dicionário foi organizado, tendo em conta, sobretudo, a disposição das entradas, a seleção dos lemas e o tamanho da nomenclatura. Trata-se de uma primeira tentativa, suscetível de ser ampliada no futuro, por isso, a nomenclatura é seletiva e pretende conciliar um conjunto representativo de provérbios da língua padrão do Brasil com outro grupo de provérbios menos frequentes, porém, também representativos e usados na língua escrita brasileira. Pelo contrário, a microestrutura é profunda, uma vez que serão necessárias explicações linguísticas, históricas e, sobretudo, tradutológicas, devido ao caráter marcadamente cultural dos provérbios.

Para ilustrar como se projetou o dicionário, foram separados dois exemplos que apresentam diferentes problemas de tradução. 0 verbete é formado pela entrada ou lema; a variante é registrada abaixo da entrada; vem a seguir a definição, que pretende ser o mais concisa possível e expressar em outras palavras o conteúdo conceptual do provérbio; depois oferecemos três contextos, com a fonte em letra de corpo menor, e ao lado de cada contexto damos a tradução acompanhada de um comentário; por fim, as observações que recolhem outros aspectos tradutológicos, linguísticos ou históricos relacionados à parêmia brasileira. Sendo um dicionário orientado a estudantes de tradução, o eixo que articula o verbete é o comentário de cada proposta tradutória para que os alunos possam tomar decisões de maneira consciente. 
Como parte da "megaestrutura", o dicionário contará com um texto externo. A introdução deve proporcionar informação sobre os objetivos, a seleção dos provérbios, os pressupostos teóricos que norteiam a elaboração de uma obra destas características e as instruções de uso e manuseio do dicionário. Especial atenção deverá ser dada à explicação da estrutura do verbete e às estratégias e técnicas de tradução empregadas a fim de incentivar a reflexão sobre os problemas de equivalência que envolve a tradução das parêmias.

Cumpre indicar, por último, que cada obra é única, em função do direcionamento e do tratamento do objeto de análise, e que cada provérbio pode assumir, na atualização discursiva, uma nova roupagem; tudo isso se coloca como um desafio para o tradutor aprendiz. Assim, concebe-se que este projeto é mais um contributo para a investigação que concilia lexicografia, paremiologia e ensino da tradução.

\section{REFERÊNCIAS}

AULETE, F. J. C.; VALENTE, A. L. S. Dicionário Online Caldas Aulete. Rio de Janeiro: Lexikon Editora Digital. Disponível em: aulete.com.br. Acesso em: 10 ago. 2019.

BARBOSA, M. A. Estrutura, funções e processos de produção de dicionários terminológicos multilíngues. Revista do GELNE, ano 1, n. 2, p. 41-44, 1999.

BUGUEÑO MIRANDA, F. V. O que é macroestrutura no dicionário de língua? In: ISQUERDO, A. N.; ALVES, I. M. (org.). As ciências do léxico: lexicologia, lexicografia e terminologia. v. 3. Campo Grande: Editora UFMS; São Paulo: Humanitas, 2007. p. 261272.

CASTELEIRO, J. M. (coord.). Dicionário da Língua Portuguesa Contemporânea. Lisboa: Academia das Ciências de Lisboa; Editorial Verbo, 2001. 2 v.

CORPAS PASTOR, G. La creatividad fraseológica: efectos semántico-pragmáticos y estrategias de traducción. Paremia, n. 10, p. 67-78, 2001.

CORPAS PASTOR, G. Manual de fraseología española. Madrid: Gredos, 1996.

CORPAS PASTOR, G.; LEIVA ROJO, J.; VARELA SALINAS, M. J. El papel del diccionario en la formación de traductores e intérpretes: análisis de necesidades y encuestas de uso. In: AYALA CASTRO, M. C. (coord.). Diccionarios y enseñanza. Alcalá de Henares: Universidad de Alcalá, 2001. p. 239-273. 
FERREIRA, A. B. de H. Novo Dicionário Eletrônico Aurélio versão 7.0. 5. ed. Curitiba: Positivo Informática, 2010.

FONSECA, H. C. Ensino e aprendizagem de fraseologismos zoônimos: proposta de interface web e dicionário bilíngue português e francês. 2017. Tese (Doutorado em Estudos Linguísticos) - Instituto de Biociências, Letras e Ciências Exatas, Universidade Estadual Paulista "Júlio de Mesquita Filho", São José do Rio Preto, 2017.

FONSECA, H. C. La web como corpus y base de investigación científica. In: CORPAS PASTOR, G. (org.). Fraseología computacional y basada en corpus: perspectivas monolingües y multilingües. Ginebra: Éditions Tradulex, 2016.

HOUAISS, A.; VILLAR, M. S. Dicionário Eletrônico Houaiss de Língua Portuguesa. Rio de Janeiro: Objetiva, 2009.

LACERDA, R. C.; LACERDA, H. R. C.; ABREU, E. S. Dicionário de provérbios: francês, português, inglês. Rio de Janeiro: Lacerda, 1999.

MACHADO, J. P. O Grande Livro dos Provérbios. Lisboa: Editorial Notícias, 1996.

MATTOS, M. Proposta de marco e microestrutura para um dicionário especial de locuções verbais - português-espanhol. 2010. Dissertação (Mestrado em Estudos de Linguagem) - Instituto de Letras, Universidade Federal do Rio Grande do Sul, Porto Alegre.

MOTA, L. Adagiário brasileiro. Fortaleza: Imprensa Universitária, 1982.

NASCENTES, A. Tesouro da fraseologia brasileira. Rio de Janeiro: Editora Freitas Bastos, 1945.

OLÍMPIO DE OLIVEIRA SILVA, M. E. Fraseografía teórica y práctica. Frankfurt am Main: Peter Lang, 2007.

PAMIES BERTRÁN, A. Comparaison inter-linguistique et comparaison interculturelle. In: QUITOUT, M. (ed.). Traduction, proverbs \& Traductologie. Paris: Éditions L'Harmattan, 2008. p. 143-156.

PARENTE, S. O Livro dos Provérbios. Lisboa: Âncora Editora, 2005. 
PENADÉS MARTÍNEZ, I. Para un diccionario de locuciones: de la lingüística teórica a la fraseografía práctica. Alcalá: Universidad de Alcalá, 2015.

RIVA, H. C. Dicionário onomasiológico de expressões idiomáticas usuais na língua portuguesa no Brasil. 2009. Tese (Doutorado em Estudos Linguísticos) - Instituto de Biociências, Letras e Ciências Exatas, Universidade Estadual Paulista "Júlio de Mesquita Filho", São José do Rio Preto, 2009.

SABIO PINILLA, J. A. Para um dicionário de provérbios Português-Espanhol: proposta de verbete. Guavira Letras, n. 27, p. 62-74, 2018.

SABIO PINILLA, J. A.; DÍAZ FERRERO, A. M. Mínimo paremiológico do portugués europeu: correspondências e equivalências em Espanhol. In: ISQUERDO, A. N.; DAL CORNO, G. O. M. (org.). As ciências do léxico: lexicologia, lexicografia, terminologia. v. 8. Campo Grande: Editora UFMS, 2018. p. 39-58.

SEVILLA ÁLVAREZ, J.; CRIDA MUÑOZ, C. A. Taxonomía de las paremias en lengua española. Phrasis. Rivista di studi fraseologici e paremiologici, v. 1, 2017. Disponível em: http://www.phrasis.it/rivista/index.php/rp/article/view/18. Acesso em: 03 ago. 2019.

URBANO, H. Dicionário brasileiro de expressões idiomáticas e ditos populares: desatando nós. São Paulo: Cortez Editora, 2018.

WELKER, H. A. Dicionários: uma pequena introdução à lexicografia. 2. ed. Brasília: Thesaurus, 2004.

XATARA, C. M. A tradução para o português de expressões idiomáticas em francês. 1998. Tese (Doutorado em Linguística e Língua Portuguesa) - Faculdade de Ciências e Letras, Universidade Estadual Paulista "Júlio de Mesquita Filho", Araraquara, 1998.

XATARA, C. M. Os dicionários bilíngües e o problema da tradução. In: OLIVEIRA, A. M. P. P.; ISQUERDO, A. N. (org.). v. 1. As ciências do léxico: lexicologia, lexicografia, terminologia. Campo Grande: Editora UFMS, 1998. p. 179-186.

XATARA, C. M.; OLIVEIRA, W. L. Novo PIP: dicionário de provérbios, idiomatismos e palavrões em uso francês-português / português-francês. São Paulo: Cultura, 2008. 
ZAVAGLIA, C. Elaboração de um dicionário temático de homônimos frequentes semibilíngüe (DTHFS) português-italiano: uma proposta. Fragmentos, n. 21, p. 53-59, jul.-dez. 2001.

ZULUAGA, A. Análisis y traducción de unidades fraseológicas desautomatizadas. Phin., n. 16, p. 67-83, 2001 [não paginado]. Disponível em: http://web.fu-berlin.de/phin/phin16/ p16t5.htm. Acesso em: 04 ago. 2019. 